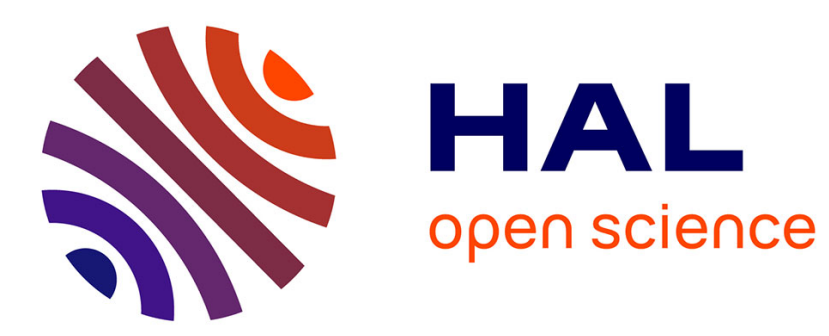

\title{
Comprehensive study of acid gelation of heated milk with model protein systems
}

Marie-Hélène Famelart, Jérome Tomazewski, Michel Piot, Stéphane Pezennec

\section{To cite this version:}

Marie-Hélène Famelart, Jérome Tomazewski, Michel Piot, Stéphane Pezennec. Comprehensive study of acid gelation of heated milk with model protein systems. International Dairy Journal, 2004, 14 (4), pp.313-321. 10.1016/j.idairyj.2003.10.009 . hal-02263102

\section{HAL Id: hal-02263102 \\ https://hal.science/hal-02263102}

Submitted on 2 Aug 2019

HAL is a multi-disciplinary open access archive for the deposit and dissemination of scientific research documents, whether they are published or not. The documents may come from teaching and research institutions in France or abroad, or from public or private research centers.
L'archive ouverte pluridisciplinaire $\mathbf{H A L}$, est destinée au dépôt et à la diffusion de documents scientifiques de niveau recherche, publiés ou non, émanant des établissements d'enseignement et de recherche français ou étrangers, des laboratoires publics ou privés. 


\title{
Comprehensive study of acid gelation of heated milk with model protein systems
}

\author{
Marie-Hélène Famelart*, Jérome Tomazewski, Michel Piot, Stéphane Pezennec \\ Laboratoire de Recherches de Technologie Laitière, Institut National de la Recherche Agronomique, 65, rue de St Brieuc, 35042 Rennes cedex, France
}

Received 9 January 2003; accepted 22 October 2003

\begin{abstract}
The effect of heat treatment of milk on the formation of acid gels was investigated using model protein systems. Protein systems contained micellar casein alone $\left(35 \mathrm{~g} \mathrm{~kg}^{-1}\right)$ (systR) or in the combination with either $\beta$-lactoglobulin $(\beta \mathrm{LG})\left(4 \mathrm{~g} \mathrm{~kg}^{-1}\right.$; systB) or egg ovalbumin $\left(4 \mathrm{~g} \mathrm{~kg}^{-1}\right.$; systO). Proteins in a milk ultrafiltrate (UF) were heat-treated at $90^{\circ} \mathrm{C}$ for 24 min. The same heat-treated systems without casein were also prepared: the UF alone (systUFR), with $\beta \mathrm{LG}\left(4 \mathrm{~g} \mathrm{~kg}^{-1}\right.$; systUFB) and with ovalbumin (4 $\mathrm{g} \mathrm{kg}$; systUFO). Proteins in pellet and supernatant fractions were analysed using reverse-phase high-pressure liquid chromatography and sodium dodecyl sulphate polyacrylamide gel electrophoresis. The solubility of globular proteins in heated systUFB and heated systUFO was determined at $\mathrm{pH} 1.6-6.5$ by absorbance measurements. Rheological changes during gelation with a starter at $42^{\circ} \mathrm{C}$ were determined and microstructures of gels by scanning electron microscopy. High quantities of $\kappa$-casein and $\beta \mathrm{LG}$ in the form of complexes (disrupted by 2-mercaptoethanol) were found in supernatant of heated systB and not in that of systO. The gelation $\mathrm{pH}$ was related to the solubility of the globular proteins, and the gelation pattern for systB and systO resembled that of heated milk and the systR pattern resembled that of unheated milk. The gels of systR were coarse and consisted of large particles. Particles in gels from systB and systO were smaller and less clustered. Although the two globular proteins behave differently during heating, they both confer to the casein micelles their solubility properties as a function of $\mathrm{pH}$. A model is presented where both soluble and colloidal complexes including the globular protein interact at $\mathrm{pH} 5.5$ and initiate the acid gelation.
\end{abstract}

(C) 2003 Elsevier Ltd. All rights reserved.

Keywords: Ovalbumin; $\beta$-lactoglobulin; Yoghurt; Heat treatment; Microstructure

\section{Introduction}

Heat treatment is generally applied to milk for safety reasons. In the yoghurt process, milk is heat-treated at $80-90^{\circ} \mathrm{C}$ for $5-10 \mathrm{~min}$ and this step leads to higher $\mathrm{pH}$ value at gelation. It has a marked influence on the microstructure of the protein network and on gelation in comparison to unheated milk, leading to a considerable increase in gel firmness and to a reduction in the amount of whey expelled from yoghurt (Harwalkar \& Kalab, 1983; Dannenberg \& Kessler, 1988a; Lucey, Munro, \& Singh, 1999). The decrease in $\tan \delta$ at the time of gel formation is followed by a maximum and then a final decrease (Lucey \& Singh, 1998d; Lucey, Tamehana, Singh, \& Munro, 1998b). According to Lucey, Tamehana, Singh, and Munro (1998a), the early increase in

*Corresponding author. Tel.: + 33-2-99-28-53-43; fax: + 33-2-23-4853-50.

E-mail address: famelart@rennes.inra.fr (M.-H. Famelart). modulus and the early decrease in $\tan \delta$ are more probably due to whey protein interactions, while the increase in modulus after the maximum involves casein interactions.

Caseins are remarkably stable at high temperatures, due to the low level of secondary and tertiary structures. In contrast, whey proteins are highly susceptible to heatinduced denaturation. Studies of individual whey proteins in a synthetic milk ultrafiltrate (SMUF) show that $\beta$-lactoglobulin $(\beta \mathrm{LG})$ has a denaturation temperature of $72.8^{\circ} \mathrm{C}$ (Ruegg, Moor, \& Blanc, 1977). The reaction is second order when heating is performed in sweet whey (Jelen \& Rattray, 1995), and is characterised by two endothermic peaks at $80^{\circ} \mathrm{C}$ and $140^{\circ} \mathrm{C}$ and two successive stages (Dannenberg \& Kessler, 1988b). Denaturation of $\alpha$-lactalbumin ( $\alpha$ lac) is reversible after heating at $20-110^{\circ} \mathrm{C}$ (Ruegg et al., 1977), but prolonged heating $(10-30 \mathrm{~min})$ leads to irreversible denaturation and aggregation (Chaplin \& Lyster, 1986). The reaction is first order and a denaturation temperature of $65.2^{\circ} \mathrm{C}$ 
has been reported in an SMUF (Ruegg et al., 1977; Dannenberg \& Kessler, 1988c). When heat treatment above $80^{\circ} \mathrm{C}$ is applied in milk, $\beta$ LG interacts with casein micelles involving $\kappa$-casein, via sulphydryl-disulphide interchange reactions and hydrophobic interactions (Singh, 1995). $\alpha$ Lac interacts with casein in the presence of $\beta \mathrm{LG}$, probably through the formation of complexes between $\alpha$ lac and $\beta$ LG that interact with casein (Elfagm \& Wheelock, 1977). Snoeren and Van Der Spek (1977) reported that $\alpha_{\mathrm{S} 2}$-caseins were also present in these complexes formed during UHT treatments. If the $\mathrm{pH}$ prior to heating is $<6.7$, denatured whey proteins associate with the micelle, while at $\mathrm{pH}>6.7$, a high quantity of denatured whey proteins/ $/$-casein complexes dissociates into the permeate (Singh, 1995).

The aim of the present study was to understand the role of heat treatment of milk at $90^{\circ} \mathrm{C}$ for more than $10 \mathrm{~min}$ on the formation of the set yoghurt. The main originality of our work consists in the use of a model protein system containing micellar casein, either alone or with a globular protein. We showed that this model compares successfully to milk. In addition, to understand the role of whey protein interactions with caseins via sulphydryl-disulphide exchanges, egg ovalbumin was used in this model, essentially because it possesses four free thiol groups. Its $\mathrm{pH}_{\mathrm{I}}$ is 4.75 (Kitabatake, Ishida, \& Doi, 1988) (compared to 5.1 for $\beta \mathrm{LG}$, Verheul, 1998) and its molecular mass is $45 \mathrm{kDa}$ (Croguennec, Nau, Pezennec, \& Brulé, 2000) (compared to $18 \mathrm{kDa}$ for $\beta \mathrm{LG}$, Hoffmann, 1997).

\section{Materials and methods}

\subsection{System preparation}

\subsubsection{Casein}

Micellar casein was prepared by microfiltration of skim milk on a $0.1 \mu \mathrm{m}$ membrane (Exekia, Bazet, France) at $50^{\circ} \mathrm{C}$ to a volume concentration factor (VCF) of 3 and diafiltered four times with de-ionised water. The retentate was freeze-dried.

\subsection{2. $\beta$-Lactoglobulin}

$\beta$ LG was supplied by J. Fauquant (Laboratoire de Recherches de Technologie Laitière INRA, Rennes, France). It was prepared from a whey protein concentrate by precipitation of alac by the addition of $3 \mathrm{~mol} \mathrm{~L}^{-1}$ citric acid to $\mathrm{pH} 3.8$, heat treatment at $56^{\circ} \mathrm{C}$ for $30 \mathrm{~min}$, microfiltration of the soluble part on a $0.1 \mu \mathrm{m}$ membrane and diafiltration with 10 volumes of water at $\mathrm{pH}$ 3.8. The filtrate and the diafiltrate containing $\beta \mathrm{LG}$ were concentrated on a DDS plane membrane (GEA, Soeborg, Denmark; molecular mass cut-off, $10 \mathrm{kDa})$ and freeze-dried.

\subsubsection{Ovalbumin}

Egg albumen was separated from commercial eggs and diluted ( 1 in 3 ) with MilliQ water. The $\mathrm{pH}$ was adjusted to 6 with $1 \mathrm{~mol} \mathrm{~L}^{-1} \mathrm{HCl}$ and stored overnight at $4{ }^{\circ} \mathrm{C}$. Following centrifugation at $2000 \mathrm{~g}$ for $3 \mathrm{~min}$ at $20^{\circ} \mathrm{C}$, the supernatant was adjusted to $\mathrm{pH} 8$ with $1 \mathrm{~mol} \mathrm{~L}^{-1} \mathrm{NaOH}$, and centrifuged at $25,000 \mathrm{~g}$ for $20 \mathrm{~min}$ just before injection on the separation column to exclude aggregates. Preparative chromatography was performed on a Q Sepharose Fast Flow column (Pezennec et al., 2000). The eluate fraction of ovalbumin was concentrated and diafiltered on an Omega $10 \mathrm{kDa}$ membrane (Filtron, Coignières, France) and freeze-dried.

\subsubsection{Milk ultrafiltrate}

Milk ultrafiltrate (UF) was prepared from fresh pasteurised milk on an $8 \mathrm{kDa}$ TAMI membrane (Tami Industries, Nyons, France) and stored at $4{ }^{\circ} \mathrm{C}$ after sterilisation on a $0.2 \mu \mathrm{m}$ sterile Nalgene membrane.

\subsubsection{Suspensions}

Casein at $35 \mathrm{~g} \mathrm{~kg}^{-1}$, alone or with either $\beta \mathrm{LG}$ or ovalbumin at $4 \mathrm{~g} \mathrm{~kg}^{-1}$, was dissolved in the milk UF by vigorous agitation followed by gentle agitation for $1 \mathrm{~h}$. In all, $27 \mathrm{~g}$ of the resulting suspension was introduced into a glass tube containing $12.5 \mathrm{mg}$ of yeast extract (Bio Springer, Maisons-Alfort, France). Three tubes were prepared and heat-treated together. Heat treatment was performed at $90^{\circ} \mathrm{C}$ for $24 \mathrm{~min}$, taking $14 \mathrm{~min}$ to reach $90^{\circ} \mathrm{C}$. The systems are referred to as syst $\mathrm{R}$ (with casein alone), systB (with casein and $\beta \mathrm{LG}$ ) or systO (with casein and ovalbumin).

Systems without casein were also prepared in UF at the same globular protein concentration and heattreated the same way as suspensions, and are referred to as systUFR (UF alone), systUFB (UF with $\beta$ LG) and systUFO (UF with ovalbumin).

\subsection{Analysis}

\subsubsection{Unpelleted casein}

The sedimentation of proteins in the different systems was performed by centrifugation of a $5 \mathrm{~mL}$ sample at $50,000 \mathrm{~g}$ for $90 \mathrm{~min}$ at room temperature. The separation was performed on an L8-55 ultracentrifuge with an Sw55.Ti rotor (Beckman Instruments France S.A., Gagny, France). Supernatants and pellets were frozen and stored before analysis by sodium dodecyl sulphate polyacrylamide gel electrophoresis (SDS-PAGE) and high-pressure liquid chromatography (HPLC).

\subsubsection{Sodium dodecyl sulphate polyacrylamide gel electrophoresis}

Each pellet was resuspended in $10 \mathrm{~g} \mathrm{Na}_{2}$ EDTA-Na EDTA (25 g L $\left.{ }^{-1}, \mathrm{pH} 6.8\right)$. Water (10 g) was added to the suspension and the suspension was stirred at $4{ }^{\circ} \mathrm{C}$ 
overnight. A portion of the resulting resuspended pellet $(4 \mathrm{~g})$ was precipitated at $\mathrm{pH} 4.6$ with $1 \mathrm{~mol} \mathrm{~L}^{-1} \mathrm{HCl}$ $(\sim 130 \mu \mathrm{L})$ at room temperature and centrifuged $(1000 \mathrm{~g}$, $15 \mathrm{~min}, 20^{\circ} \mathrm{C}$ ). Pellets were washed with water at $\mathrm{pH} 4.6$, then centrifuged $\left(1000 \mathrm{~g}, 15 \mathrm{~min}, 20^{\circ} \mathrm{C}\right)$ and finally resuspended in $10 \mathrm{mmol} \mathrm{L}^{-1}$ Tris $-10 \mathrm{mmol} \mathrm{L}^{-1} \mathrm{Na}_{2}$ EDTA, $25 \mathrm{~g} \mathrm{~L}^{-1}$ SDS at $\mathrm{pH} 8.2$ and frozen. This fraction, called the micellar acid-precipitable fraction, should contain micellar casein, as well as denatured globular proteins either as large polymers or associated with micellar casein.

Supernatants $(0.5 \mathrm{~mL})$ were precipitated at $\mathrm{pH} 4.6$, washed with water at $\mathrm{pH} 4.6$, resuspended and frozen as for pellets. This fraction, called the soluble acidprecipitable fraction, should contain the soluble caseins or the soluble casein-whey protein complexes and denatured whey proteins in small aggregates.

Samples of the micellar fraction $(10 \mu \mathrm{L})$ and soluble fraction $(20 \mu \mathrm{L})$ with and without reduction at $37^{\circ} \mathrm{C}$ for $1 \mathrm{~h}$ with 2 -mercaptoethanol $\left(0.71 \mathrm{~mol} \mathrm{~L}^{-1}\right.$ final concentration) were examined by SDS-PAGE $\left(150 \mathrm{~g} \mathrm{~L}^{-1}\right)$ using the MiniProtean II system (Biorad, Ivry sur Seine, France). Staining was performed with Coomassie Blue and lanes were scanned with Bioimage Software (Millipore, Saint Quentin-en-Yvelynes). A prestained low-range SDS-PAGE standard (Biorad, ref 161-0305; molar weight from 14 to $94 \mathrm{kDa}$ ) was also loaded.

\subsubsection{Reverse-phase HPLC}

Unpelleted casein present in the supernatant (prepared at $50,000 \mathrm{~g}$ ) was estimated by reverse-phase HPLC (RP-HPLC) on a $\mathrm{C}_{4}$ Vidac 214 TP 54 column (Interchim, Montluçon, France) at $40^{\circ} \mathrm{C}$. Solvent A consisted of $1.06 \mathrm{~mL} \mathrm{~L}^{-1}$ trifluoroacetic acid (TFA) in water and solvent $\mathrm{B}$ consisted of $1 \mathrm{~mL} \mathrm{~L}^{-1}$ TFA in $80 \%$ acetonitrile in water. A linear gradient at $1 \mathrm{~mL} \min ^{-1}$ from $37 \%$ to $54 \%$ B was performed in $30 \mathrm{~min}$ and $100 \%$ B was applied over $32 \mathrm{~min}$. Proteins were detected at $280 \mathrm{~nm}$. Supernatants were diluted $3: 4$ in a solvent composed of $8 \mathrm{~mol} \mathrm{~L}^{-1}$ urea, $1 \mathrm{~mol} \mathrm{~L}^{-1}$ Tris, $13 \mathrm{~g} \mathrm{~L}^{-1}$ sodium citrate at $\mathrm{pH} 7$, then 9:10 in an aqueous solution of $30 \mathrm{~g} \mathrm{~L}^{-1}$ dithiothreitol and then 1:10 in solvent $\mathrm{A}$. The fraction $(\%)$ of unpelleted casein was determined by calculating the ratio of the peak area of the corresponding casein in the supernatant to the area of the same peak in the unheated suspension. Two injections were performed.

\subsubsection{Gelation}

The heated systems were equilibrated at $42^{\circ} \mathrm{C}$ for $15 \mathrm{~min}$ and were inoculated with lyophilised non-ropy cultures of $S$. thermophilus ST060 at $2.10^{6}$ colony forming units (CFU) $\mathrm{mL}^{-1}$ and L. bulgaricus LB340 at $2.10^{5} \mathrm{CFU} \mathrm{mL}^{-1}$ (Texel, Rhodia Food, Dangé Saint Romain, France).
The kinetics of acidification were monitored using a thin $\mathrm{pH}$ electrode (Inlab 423, Mettler Toledo, Paris, France) immersed in the rheometer cup. The lag phase (time for the initial $\mathrm{pH}$ to decrease by 0.01 ) lasted $\sim 1 \mathrm{~h}$ and it took $\sim 5 \mathrm{~h}$ to reach $\mathrm{pH} 4.6$.

The elastic $\left(G^{\prime}\right)$ and viscous $\left(G^{\prime \prime}\right)$ moduli and the loss tangent, $\tan \delta$, were monitored at $42^{\circ} \mathrm{C}$ as a function of time in an AR1000 rheometer (TA instruments, Waters, St Quentin en Yvelines, France), in oscillatory mode with coaxial cylinder geometry at a frequency of $1 \mathrm{~Hz}$ and a strain of 0.02 . The suspension was placed in the cup and covered with a thin layer of paraffin to prevent dehydration during incubation. Measurements were recorded dynamically at $3.36 \mathrm{~min}$ intervals. The gel time was defined as the point where $G^{\prime}>1 \mathrm{~Pa}$. Gelation was monitored on two or more occasions for each protein system.

\subsubsection{Globular protein solubility}

Samples of $\beta \mathrm{LG}$ or ovalbumin were initially dissolved in UF at $4 \mathrm{~g} \mathrm{~kg}^{-1}$, heat-treated as in 2.1 .5 and further diluted ( 1 in 5) in milk UFs adjusted from pH 6.5 to 1.6 by the addition of concentrated $\mathrm{HCl}$. The $\mathrm{pH}$ values and turbidity (absorbance at $600 \mathrm{~nm}$ ) of the diluted samples were measured against water. The diluted samples were centrifuged at $3000 \mathrm{~g}$ for $15 \mathrm{~min}$ at $20^{\circ} \mathrm{C}$ and the supernatants diluted 20 -fold in a $20 \mathrm{mmol} \mathrm{L}^{-1}$ Tris $\mathrm{HCl}, 4 \mathrm{~mol} \mathrm{~L}^{-1}$ urea buffer, $\mathrm{pH}$ 8. The absorbance of the diluted supernatant was measured at $280 \mathrm{~nm}$ against the urea buffer.

\subsubsection{Scanning electron microscopy of acid gels}

Acid gels were formed as described above. At $\mathrm{pH}$ 4.6, the gels were placed at $4{ }^{\circ} \mathrm{C}$ and stored overnight. Gels were observed by scanning electron microscopy (SEM) under a Philips XL20 (Bobigny, France) microscope. Samples were fixed in glutaraldehyde $\left(25 \mathrm{~mL} \mathrm{~L}^{-1}\right)$ in $0.1 \mathrm{~mol} \mathrm{~L}^{-1}$ sodium cacodylate buffer, $\mathrm{pH} 7.2$ for $5 \mathrm{~d}$ at $4^{\circ} \mathrm{C}$. After rinsing with cacodylate and water, pieces were dehydrated in alcohol series and critical point dried. Fractured samples were glued to the sample holder, gold coated and observed at $10 \mathrm{kV}$. For each gel, three or four photographs were taken at magnifications of $20,000 \times$ or $10,000 \times$. For each photograph, $\sim 67$ particles on average were visible and their diameters determined for each gel. The median particle size was measured as the DL 50 (in $\mathrm{nm}$ ): half of the particles were smaller in size than the DL 50, while the other half were larger.

\subsubsection{Statistical analysis}

A Student's $t$-test was used to determine if the averages of two sets of measurements were significantly different at $P<0.05$. 


\section{Results}

Suspensions of casein micelles in UF with (or without) a globular protein were prepared and heated (systR, systB, systO). The supernatant and pellet fractions from these suspensions, either heated or not, were prepared and analysed by RP-HPLC and SDS-PAGE. Acid gelation of heated systR, systB and systO was then studied by rheological measurements and SEM. Besides, UF alone, or with $\beta$ LG or ovalbumin at the same concentration as above were prepared and heated (respectively, systUFR, systUFB and systUFO). The heated systUFB and systUFO were diluted in UF adjusted from $\mathrm{pH} 6.5$ to 1.6 and the solubility of the globular protein was tested by absorbance measurements.

SystUFR, systUFB and systUFO were translucent before heat treatment. After heat treatment a cloudy appearance was observed for systUFR and systUFB and a precipitate at the bottom of the tube for systUFO. This precipitate was easily maintained in suspension after agitation. The initial $\mathrm{pH}$ value of the three heated systems was 6.66 .

Heat treatment of systB led to a considerable increase in the level of soluble $\kappa$-casein and to a decrease in the level of soluble $\alpha_{\mathrm{s} 1}$-casein (Table 1). The soluble phases of heated and unheated systems were the same, in the other systems.

Acid-precipitable bands from micellar and soluble fractions of heated and unheated systems, with and without reduction with 2-mercaptoethanol, were compared by SDS-PAGE (Fig. 1; results in the absence of reducing agent are not shown). Heating systB and systO led to the appearance of a slight band of $\beta \mathrm{LG}$ or ovalbumin in the micellar fractions and to larger bands of these proteins in the soluble fractions. The relative intensity of the $\beta \mathrm{LG}$ band in the soluble fraction of heated systB was very high. In contrast, the intensity of the ovalbumin band in the soluble fraction of systO barely increased on heating. Heat treatment of systB led to an increase in soluble $\kappa$-casein and to a decrease in soluble $\alpha_{\mathrm{s}}$-caseins. No change was evident in the distribution of casein with heat treatment in systO. When SDS-PAGE was performed without reduction of samples, neither $\beta \mathrm{LG}$ nor ovalbumin appeared in any lane of acid-precipitable fractions of systB or systO.

Gel formation in heated systR, systB and systO and the solubility of the globular proteins in heated systUFB and systUFO are presented versus the $\mathrm{pH}$ during acidification with the starter bacteria (Fig. 2). While $\tan \delta$ decreased constantly in syst $\mathrm{R}$, a local maximum of $\tan \delta$ was found at $\mathrm{pH} 4.9$ for systB and at $\mathrm{pH} 5$ for systO. The pattern for systR resembled that reported for unheated milk (Lucey et al., 1998d; Lucey, Tamehana, Singh, \& Munro, 1998b). The pattern for systB resembled that found for heated milk, which has a local maximum for $\tan \delta$ at $\mathrm{pH}$ 5.0-5.2 (Lucey, Tamehana, Singh, \& Munro, 1998a; Laligant, Famelart, Paquet, \& Brulé, 2003). The $\tan \delta$ values between $\mathrm{pH} 5.0$ and 4.0 were markedly lower for systO than for systB or systR, indicating that systO was the most elastic gel system. In systB and systO, $G^{\prime}$ increased from the gel point to $\mathrm{pH} 4$ and a shoulder was observed on the curve at $\sim \mathrm{pH}$ 5. $G^{\prime}$ values were very low for syst $\mathrm{R}$ at acid $\mathrm{pH}$, as in unheated milk, but increased to $200-250$ and $500-600 \mathrm{~Pa}$ with the addition of $\beta \mathrm{LG}$ or ovalbumin, respectively. The results indicated wide variability of $G^{\prime}$ for each protein system, probably due to the numerous stages in system preparations and to the rheological measurements, but the decrease in $\tan \delta$ was fairly reproducible.

The $\mathrm{pH}$ at gelation was $\sim 4.88 \pm 0.01,5.47 \pm 0.08$ and $5.88 \pm 0.03$ for systR, systB and systO, respectively. $\beta \mathrm{LG}$ and ovalbumin lost their solubility at $\sim \mathrm{pH} 5.5$ (systUFB) and 6.0 (systUFO) (Fig. 2).

The $\mathrm{pH}$ range of insolubilisation was much greater for ovalbumin than for $\beta \mathrm{LG}$. However, the turbidity of ovalbumin at $\mathrm{pH} 6.6$ was greater than the turbidity of $\beta \mathrm{LG}$. The absorbance of the supernatant in the $\mathrm{pH}$ range where the solubility was reduced was high, due to the absorbance of milk UF itself.

The microstructures of the acid gels from the different protein systems are shown in Fig. 3. SystR, with casein

Table 1

Percentage of each casein in the soluble phase of protein systems: micellar casein (systR), micellar casein plus $\beta$-lactoglobulin (systB) and micellar casein plus ovalbumin (systO)

\begin{tabular}{|c|c|c|c|c|c|c|}
\hline & \multicolumn{6}{|c|}{ Percentage of soluble caseins ${ }^{a}$} \\
\hline & \multicolumn{2}{|l|}{ SystR } & \multicolumn{2}{|l|}{ SystB } & \multicolumn{2}{|l|}{ SystO } \\
\hline & NHT & HT & NHT & HT & NHT & HT \\
\hline$\kappa$-cas & $12.02 \pm 2.01$ & $11.68 \pm 0.05$ & $14.97 \pm 1.64$ & $41.15 \pm 2.15$ & $13.00 \pm 0.94$ & $10.90 \pm 1.02$ \\
\hline$\alpha_{\mathrm{s} 2}$-cas & $6.62 \pm 5.16$ & $4.83 \pm 1.54$ & $4.88 \pm 1.03$ & $1.53 \pm 2.17$ & $4.06 \pm 0.71$ & $7.22 \pm 4.10$ \\
\hline$\alpha_{\mathrm{s} 1}$-cas & $5.28 \pm 1.52$ & $4.79 \pm 0.22$ & $6.76 \pm 0.54$ & $1.85 \pm 0.02$ & $5.18 \pm 0.06$ & $4.44 \pm 0.09$ \\
\hline$\beta$-cas & $8.22 \pm 2.89$ & $8.01 \pm 0.61$ & $12.78 \pm 0.95$ & $10.46 \pm 0.51$ & $8.28 \pm 0.29$ & $7.50 \pm 0.13$ \\
\hline
\end{tabular}

Note: Each of the above were either unheated (NHT) or heat treated (HT) at $90^{\circ} \mathrm{C}$ for $24 \mathrm{~min}$. Values within a row not sharing the same superscript differ significantly $(P<0.05)$. No letter means no statistical difference.

${ }^{\text {a }}$ Presented values are the means of two replicate analyses. The values after the \pm sign indicate the standard deviations. 

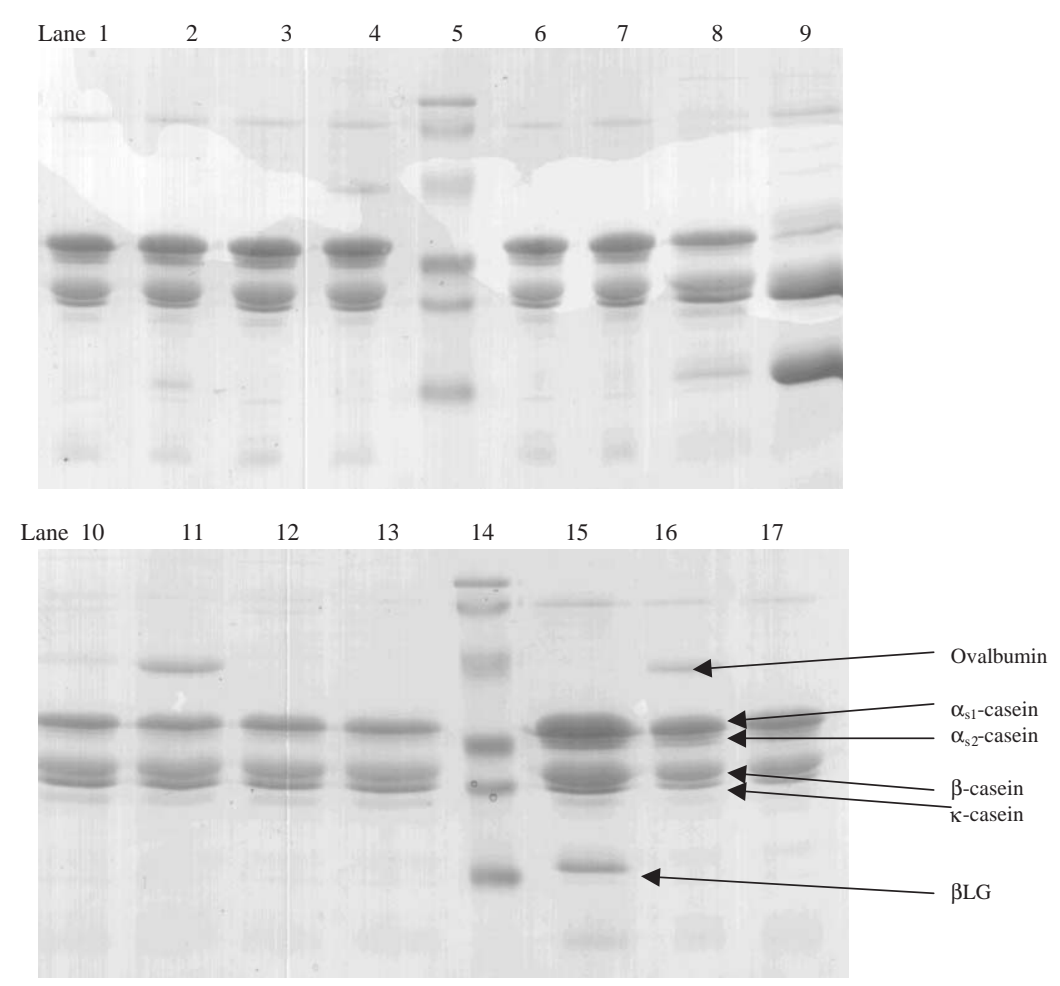

Fig. 1. SDS-PAGE analysis of micellar acid-precipitable protein, soluble acid-precipitable protein and total protein of different protein systems after reduction with 2-mercaptoethanol. The protein systems consisted of proteins suspended in a milk UF: SystR, $35 \mathrm{~g} \mathrm{~kg}^{-1}$ micellar casein; systB, $35 \mathrm{~g} \mathrm{~kg}^{-1}$ micellar casein plus $4 \mathrm{~g} \mathrm{~kg}^{-1} \beta \mathrm{LG}$; systO, $35 \mathrm{~g} \mathrm{~kg}^{-1}$ micellar casein plus $4 \mathrm{~g} \mathrm{~kg}^{-1}$ egg ovalbumin. Each of the above were either unheated or heat-treated at $90^{\circ} \mathrm{C}$ for $24 \mathrm{~min}$. Micellar and soluble protein fractions were recovered in the pellet and the supernatant, respectively, after centrifugation $\left(50,000 \mathrm{~g}, 90 \mathrm{~min}, 20^{\circ} \mathrm{C}\right)$. Acid-precipitable fractions were prepared by precipitation at $\mathrm{pH} 4.6$, and washing of the soluble and micellar fractions in water at $\mathrm{pH}$ 4.6. Micellar acid-precipitable protein fraction: unheated, lane 1 (systB), 3 (systO) and 6 (systR); heat-treated, lane 2, 4 and 7 $(10 \mu \mathrm{L}$ each, respectively); soluble acid-precipitable protein fraction, unheated, lane 8 (systB), 10 (systO) and 12 (systR); heat-treated, lane 9,11 and $13(20 \mu \mathrm{L}$ each, respectively); total protein from unheated systB, systO and systR (lane 15, 16 and 17, respectively); standards from 14 to $94 \mathrm{kDa}$ (lane 5 and $14 ; 5 \mu \mathrm{L}$ ). See text for details of protein systems and fractions, and heat treatment applied.

alone, formed a coarse gel comprised of large particles. The DL 50 of particles in gels with casein alone was found to be between 750 and $850 \mathrm{~nm}$. In contrast, particles in gels containing casein and globular proteins (i.e. systB, systO) were less clustered than those of systR (with branched chains a few particles thick and with much smaller particles). The DL 50 was at $350-500$ and $350-400 \mathrm{~nm}$ in systB and systO, respectively. Pores in gels of systB and systO were smaller and more uniformly distributed than in gels of systR.

\section{Discussion}

In heated systB and systO, $\beta \mathrm{LG}$ and ovalbumin probably aggregate in different ways. This is evident from the appearance of the heated systems: large aggregates were formed with heat treatment in the presence of ovalbumin resulting in a cloudy appearance. Considerable increase in particle size and viscosity has been reported in these heated systems containing ovalbumin (Famelart, Tomazewski, Piot, \& Pezennec, 2003).
Despite these differences, aggregation during heat treatment of syst $\mathrm{B}$ and systO yielded an increase in the gelation $\mathrm{pH}$, as compared to systR, which gelled as unheated milk in accordance with the results of Lucey et al. (1998b). In other words, the gelation $\mathrm{pH}$ of systB and systO closely paralleled the $\mathrm{pH}$ of loss of solubility of heated $\beta \mathrm{LG}$ and ovalbumin solutions, respectively. Since gelation of milk is thought to be due to a charge reduction during acidification, $\beta \mathrm{LG}$ or ovalbumin in heated systB or systO probably does not act through the negative charges they add to casein. As a matter of fact, an increase in the negative charge of casein micelles due to association with globular proteins would result in a shift of the gelation $\mathrm{pH}$ towards lower values, oppositely to what is observed. $\beta$ LG and ovalbumin could also act through the hydrophobicity they add to casein. Ovalbumin is more hydrophobic than $\beta \mathrm{LG}$, as evidenced by its higher retention in $\mathrm{C} 4$ reverse-phase chromatography (Nau, Mallard, Pages, \& Brulé, 1999). In our conditions, an association of ovalbumin with casein micelles would lead to more hydrophobic particles than the association of $\beta \mathrm{LG}$ with casein micelles. Consequently, during acidification, the particles would begin to aggregate in 


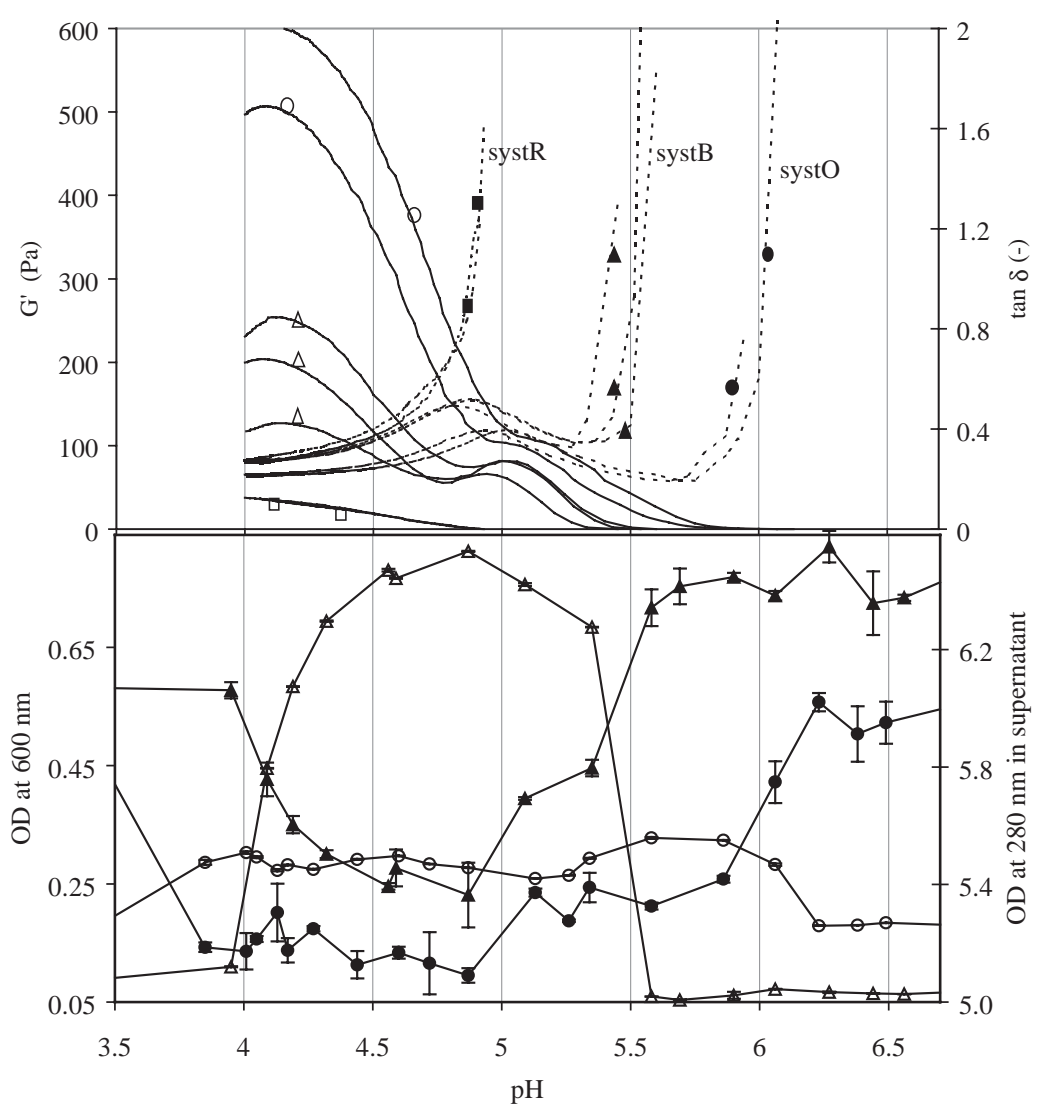

Fig. 2. (a) Effects of pH on storage modulus, $G^{\prime}$, and on $\tan \delta$ of heated $\operatorname{systR}(\mathbf{\square} ; \square)$, systB $(\mathbf{\Delta} ; \triangle)$ and systO $(\mathbf{\bullet}$; $\bigcirc)$ protein systems (as in Fig. 1). Acidification was obtained by addition of a starter and growth at $42^{\circ} \mathrm{C}$. (b) Effects of pH on the solubility of $\beta$ LG and ovalbumin dispersed in milk UF after $90^{\circ} \mathrm{C}-24 \mathrm{~min}$ heat treatment (see text for further explanation). Turbidity of heated protein systems (measured by optical density, OD, at $600 \mathrm{~nm}$ ) after dilution $1-5 \mathrm{in} \mathrm{UF}$ which had been previously adjusted from $\mathrm{pH}$ values 6.5 to $1.6(\beta \mathrm{LG}, \triangle$; ovalbumin, $\bigcirc$ ). Dilute solutions of $6.5-1.6$ $\mathrm{pH}$ were centrifuged $\left(3000 \mathrm{~g}-15 \mathrm{~min}-20^{\circ} \mathrm{C}\right)$; the supernatants were diluted 20 -fold in a Tris- $\mathrm{HCl}$ buffer containing $4 \mathrm{~mol} \mathrm{~L}{ }^{-1}$ urea at $\mathrm{pH} 8$ and the optical density was measured at $280 \mathrm{~nm}$ : $\beta \mathrm{LG}, \boldsymbol{\Delta}$; ovalbumin, $\bullet$. Error bars represent standard deviations for replicate analyses.

conditions of higher electrostatic repulsion, which is at higher $\mathrm{pH}$ values.

High proportions of $\beta \mathrm{LG}$ and ovalbumin were found in the acid-precipitable supernatant fraction and low proportions were found in the acid-precipitable pellet fraction. Heating produced unpelleted and pelleted aggregates containing a globular protein. Heat-induced co-aggregates of $\beta \mathrm{LG}$ with unpelleted $\kappa$-casein were suspected, according to previous findings (Law, 1996). If an interaction between ovalbumin and $\kappa$-casein occurred, it was not a major event, because the distribution of caseins in the unpelleted fraction of systO was not changed by the heat treatment. Heating at $90^{\circ} \mathrm{C}$ for 10 min of a whey protein-free milk at $\mathrm{pH} 6.5$ does not lead to $\kappa$-casein solubilisation as found by Anema and $\mathrm{Li}(2000)(16 \%$ of total concentration of $\kappa$-casein is found in the supernatants of a whey protein-free milk after heating at $20^{\circ} \mathrm{C}, 60^{\circ} \mathrm{C}$ or $90^{\circ} \mathrm{C}$ for $10 \mathrm{~min}$ ).

We observed that the fraction of soluble $\kappa$-casein is the same before and after the heat treatment of systO and systR. The question that thus arises is why $\beta \mathrm{LG}$ provoked solubilisation of $\kappa$-casein and why ovalbumin did not? This might be due to the greater size of ovalbumin compared to the size of $\beta \mathrm{LG}$, which could prevent the penetration of ovalbumin into the micellar structure or the accessibility of $\kappa$-casein to ovalbumin. In order to explain the interaction of $\beta \mathrm{LG}$ with $\kappa$-casein during heat treatment, two hypothesises can be made: (i) $\beta$ LG interacts with micellar $\kappa$-casein and causes its dissociation from the micelle. Disulphide interactions between $\beta$ LG and micellar $\kappa$-casein could impair the native interactions between $\kappa$-casein and the other micellar casein molecules, causing its solubilisation. (ii) Heat treatment causes the dissociation of $\kappa$-casein, and $\beta \mathrm{LG}$ and $\kappa$-casein interact in the aqueous phase. According to this hypothesis, in systR or systO, $\kappa$ casein would first dissociate into the aqueous phase, and then return to the micellar fraction during cooling exactly in the same proportion as before heat treatment, which is unlikely if one considers the casein micelle as a dynamic material. Supposing a reversible solubilisation of $\kappa$-casein during heating, it remains to be explained why it did not react with ovalbumin in the aqueous phase. First, the molar concentration of ovalbumin is 

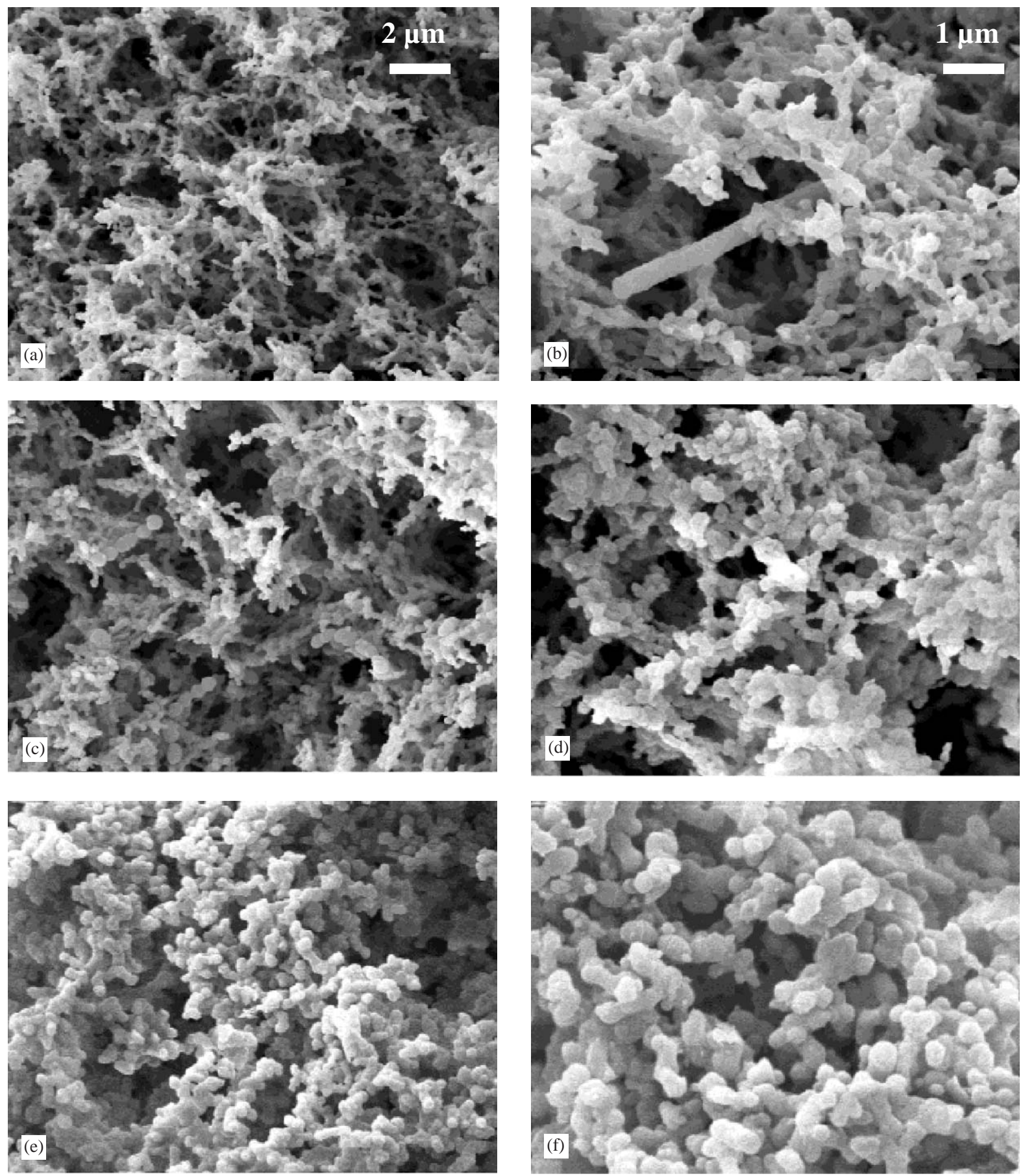

Fig. 3. Scanning electron micrographs of acid gels prepared from milk protein systems: micellar casein (systR: e and f), micellar casein plus $\beta$ LG (systB: c and d), and micellar casein plus ovalbumin (systO: a and b). The protein systems were heat-treated $\left(90^{\circ} \mathrm{C}\right.$ for $\left.24 \mathrm{~min}\right)$ prior to slow quiescent acidification at $\mathrm{pH} 4.6$, which was achieved by the addition of a starter culture to the systems at $42^{\circ} \mathrm{C}$. See text for details of protein systems and heat treatment.

$0.08 \mathrm{mmol} \mathrm{L}^{-1}$, compared to $0.27 \mathrm{mmol} \mathrm{L}^{-1}$ for $\beta \mathrm{LG}$. Second, it is possible that ovalbumin is already denatured by heat treatment, and is no longer able to interact with $\kappa$-casein.

Polymerisation of ovalbumin or of casein with ovalbumin probably occurs during heat treatment as a result of disulphide, hydrophobic and hydrogen inter- actions. As globular proteins were absent on SDSPAGE without reduction, complexation must have involved $\mathrm{SS} / \mathrm{SH}$ interchanges for $\beta \mathrm{LG}$ as for ovalbumin.

The microstructures of gels without globular proteins (systR) resembled gels obtained from unheated milk (Harwalkar \& Kalab, 1980; Parnell-Clunies, Kakuda, \& Smith, 1987). In contrast, gels with $\beta$ LG (or ovalbumin) 


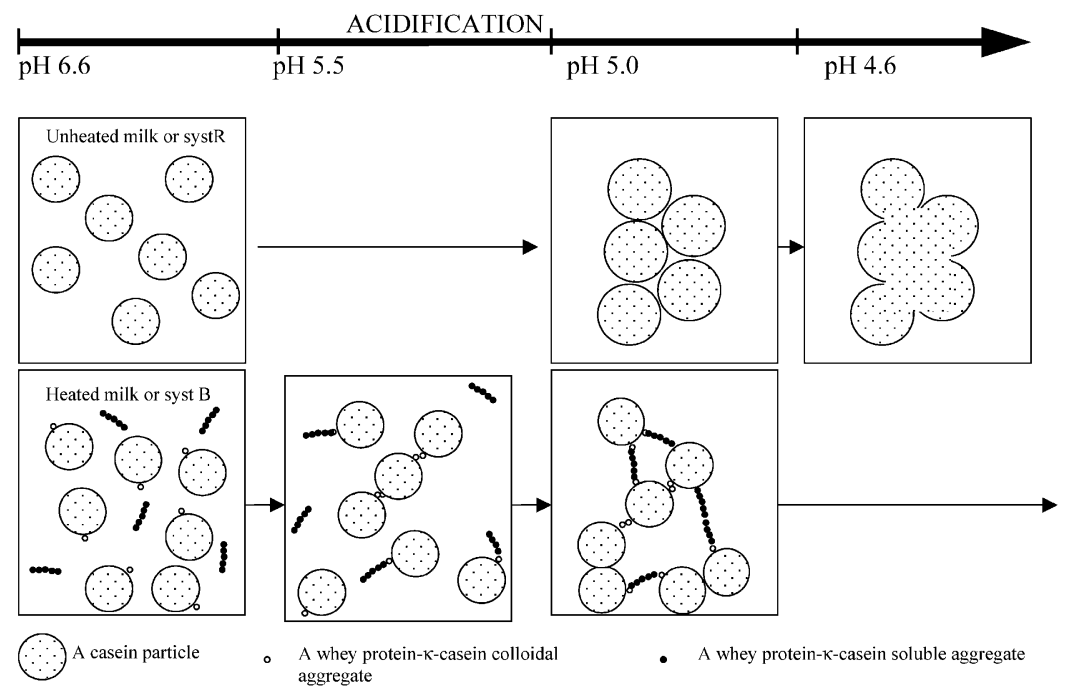

Fig. 4. Schematic diagram of the effects of heat treatment of milk on acid gel microstructure.

resembled gels obtained from heated milk. They consisted of a more branched network of smaller particles and were less heterogeneous (Kalab, Emmons, \& Sargant, 1976; Davies, Shankar, Brooker, \& Hobbs, 1978; Creamer, Berry, \& Matheson, 1978; Harwalkar et al., 1980; Parnell-Clunies et al., 1987; Lucey, Teo, Munro, \& Singh, 1998c). Heat-induced complexes of $\beta \mathrm{LG}$ and $\kappa$-casein on the micelle surface may prevent the expansion of the micelle in heated milk. This may be related to the fact that dissociation of the casein from the micelle is not observed during acidification at $30^{\circ} \mathrm{C}$ in heated milk (Law, 1996; Laligant, Famelart, Brulé, Piot, \& Paquet, 2003), whereas it occurs at $\mathrm{pH} \sim 5.6$ at $30^{\circ} \mathrm{C}$ in unheated milk (van Hooydonk, Hagedoorn, \& Boerrigter, 1986; Dalgleish \& Law, 1988).

We hypothesise that casein particles may be covered with globular proteins and that this layer may define its physicochemical properties. It is not clear whether micellar $\beta$ LG- $\kappa$-casein complexes or soluble complexes (if they exist), possibly play a role in the formation of acid gels. They are probably both involved: adding soluble and bound complexes increases $\mathrm{pH}$ at gelation, increases $\mathrm{G}^{\prime}$ values and modifies the curves of $\tan \delta$ versus $\mathrm{pH}$ (Lucey et al., 1998b). According to Kalab, Emmons, and Sargant (1976), particle size in yoghurt from unheated milk is twice that in yoghurt from heated milk. Particles in yoghurt from unheated milk are aggregated into clusters, whereas the particles form branched chains in yoghurt from heated milk. The presence of colloidal complexes or of soluble complexes leads both to small particle sizes and to a branched structure.

The early decrease in $\tan \delta$ can be attributed to aggregation of micellar $\beta \mathrm{LG}$ and soluble complexes containing $\kappa$-casein and $\beta \mathrm{LG}$ through hydrophobic interactions. Micellar casein probably aggregates later by casein-casein aggregation. Fractionation and addi- tion of these complexes to unheated milk should confirm this hypothesis.

A model of acid gelation of unheated and heated milk is given in Fig. 4. Casein particles swell in unheated milk, due to the solubilisation of casein at $\mathrm{pH} \sim 5.2$ and aggregate at $\mathrm{pH} \sim 5.0$. Particles fuse together until $\mathrm{pH}$ 4.6. According to Creamer et al. (1978) and Creamer and Matheson (1980), soluble heat-induced aggregates occur as thread-like particles in heated milk, and colloidal heat-induced aggregates are present. They both interact at $\mathrm{pH} \sim 5.5$, leading to the first increase in $G^{\prime}$. Then casein-casein interactions take place at $\mathrm{pH}$ $\sim 5.0$, leading to the second increase in $G^{\prime}$. In this model, both types of aggregate play a role in the gelation kinetics and in network firmness.

\section{Conclusions}

The goal of this work was to understand how casein and $\beta$-LG interact during heat treatment of milk and how the behaviour of heated milk is affected during acid gelation. Our approach was to use in parallel with $\beta$-LG a globular protein with different physico-chemical properties in milk model systems.

Our results first show that the added globular proteins confer to the casein micelles their properties of solubility as a function of $\mathrm{pH}$.

The two globular proteins exhibited distinct behaviours as concerns their interaction with $\kappa$-casein. We could not observe the solubilisation of $\kappa$-casein when ovalbumin was added instead of $\beta$-LG, but ovalbumin did markedly increase the gelation $\mathrm{pH}$ and the final elastic modulus of the gel. In order to explain these results, a model is proposed in which both soluble and colloidal complexes between $\beta$-LG and $\kappa$-casein participate to the gel network formation. 
This model has now to be improved in order to account for the differences between ovalbumin and $\beta$-LG, with the aim of getting further insights in the role of $\beta$-LG, in particular as regards its interaction with $\kappa$-casein.

\section{Acknowledgements}

The authors thank J. Fauquant for providing $\beta$-lactoglobulin.

\section{References}

Anema, S. G., \& Li, Y. (2000). Further studies on the heat-induced, $\mathrm{pH}$ dependent dissociation of casein from the micelles in reconstituted skim milk. Lebensmitel-Wissenschaft und-Technologie, 33(5), 335-343.

Chaplin, L. C., \& Lyster, R. L. J. (1986). Irreversible heat denaturation of bovine $\alpha$-lactalbumin. Journal of Dairy Research, 53(2), 249-258.

Creamer, L. K., Berry, G. P., \& Matheson, A. R. (1978). The effect of $\mathrm{pH}$ on protein aggregation in heated skim milk. New Zealand Journal of Dairy Science and Technology, 13(1), 9-15.

Creamer, L. K., \& Matheson, A. R. (1980). Effect of heat treatment on the proteins of pasteurized skim milk. New Zealand Journal of Dairy Science and Technology, 15, 37-49.

Croguennec, T., Nau, F., Pezennec, S., \& Brulé, G. (2000). Simple rapid procedure for preparation of large quantities of ovalbumin. Journal of Agricultural and Food Chemistry, 48(10), 4883-4889.

Dalgleish, D. G., \& Law, A. J. R. (1988). pH-induced dissociation of bovine casein micelles. I. Analysis of liberated caseins. Journal of Dairy Research, 55(4), 529-538.

Dannenberg, F., \& Kessler, H. G. (1988a). Effect of denaturation of $\beta$-lactoglobulin on texture properties of set-style nonfat yoghurt. 1. Syneresis. Milchwissenschaft, 43(11), 632-635.

Dannenberg, F., \& Kessler, H. G. (1988b). Thermodynamic approach to kinetics of $\beta$-lactoglobulin denaturation in heated skim milk and sweet whey. Milchwissenschaft, 43(3), 139-142.

Dannenberg, F., \& Kessler, H. G. (1988c). Application of reaction kinetics to the denaturation of whey proteins in heated milk. Milchwissenschaft, 43(1), 3-7.

Davies, F. L., Shankar, P. A., Brooker, B. E., \& Hobbs, D. G. (1978). A heat-induced change in the ultrastructure of milk and its effect on gel formation in yoghurt. Journal of Dairy Research, 45(1), 53-58.

Elfagm, A. A., \& Wheelock, J. V. (1977). Effect of heat on $\alpha$-lactalbumin and $\beta$-lactoglobulin in bovine milk. Journal of Dairy Research, 44(2), 367-371.

Famelart, M. H., Tomazewski, J., Piot, M., \& Pezennec, S. (2003). Comparison of rheological properties of acid gels made from heated casein combined with $\beta$-lactoglobulin or egg ovalbumin. International Dairy Journal, 13, 123-124.

Harwalkar, V. R., \& Kalab, M. (1980). Milk gel structure. XI. Electron microscopy of glucono-delta-lactone-induced skim milk gels. Journal of Texture Studies, 11(1), 35-49.

Harwalkar, V. R., \& Kalab, M. (1983). Susceptibility of yoghurt to syneresis. Comparison of centrifugation and drainage methods. Milchwissenschaft, 38(9), 517-522.

Hoffmann, M. (1997). $\beta$-Lactoglobulin: Denaturation and aggregation. Ph.D. thesis, NIZO.

Jelen, P., \& Rattray, W. (1995). Thermal denaturation of whey proteins. In International Dairy Federation (Ed.), Heat-induced changes in milk, Vol. 9501 (pp. 66-85). Brussels: International Dairy Federation.

Kalab, M., Emmons, D. B., \& Sargant, A. G. (1976). Milk gel structure. V. Microstructure of yoghurt as related to the heating of milk. Milchwissenschaft, 31(7), 402-408.

Kitabatake, N., Ishida, A., \& Doi, E. (1988). Physicochemical and functional properties of hen ovalbumin dephosphorylated by acid phosphatase. Agricultural and Biological Chemistry, 52(4), 967-973.

Laligant, A., Famelart, M. H., Brulé, G., Piot, M., \& Paquet, D. (2003). Fermentation by lactic bacteria at two temperatures of preheated reconstituted milk. I. Behaviour of proteins and minerals. Le Lait, 83, 181-192.

Laligant, A., Famelart, M. H., Paquet, D., \& Brulé, G. (2003). Fermentation by lactic bacteria at two temperatures of pre-heated reconstituted milk. II. Dynamic approach of the gel construction. Le Lait, 83, 307-320.

Law, A. J. R. (1996). Effects of heat treatment and acidification on the dissociation of bovine casein micelles. Journal of Dairy Research, 63(1), 35-48.

Lucey, J. A., Munro, P. A., \& Singh, H. (1999). Effects of heat treatment and whey protein addition on the rheological properties and structure of acid skim milk gels. International Dairy Journal, $9(3 / 6), 275-279$.

Lucey, J. A., Tamehana, M., Singh, H., \& Munro, P. A. (1998a). A comparison of the formation, rheological properties and microstructure of acid skim milk gels made with a bacterial culture or glucono-delta-lactone. Food Research International, 31(2), $147-155$

Lucey, J. A., Tamehana, M., Singh, H., \& Munro, P. A. (1998b). Effect of interactions between denatured whey proteins and casein micelles on the formation and rheological properties of acid skim milk gels. Journal of Dairy Research, 65(4), 555-567.

Lucey, J. A., Teo, C. T., Munro, P. A., \& Singh, H. (1998c). Microstructure, permeability and appearance of acid gels made from heated skim milk. Food Hydrocolloids, 12(2), 159-165.

Lucey, J. A., \& Singh, H. (1998d). Formation and physical properties of acid milk gels: A review. Food Research International, 30(7), 529-542.

Nau, F., Mallard, A., Pages, J., \& Brulé, G. (1999). Reversed-phase liquid chromatography of egg white proteins. Optimization of ovalbumin elution. Journal of Liquid Chromatography and Related Technology, 22(8), 1129-1147.

Parnell-Clunies, E., Kakuda, Y., \& Smith, A. K. (1987). Microstructure of yogurt as affected by heat treatment of milk. Milchwissenschaft, 42(7), 413-417.

Pezennec, S., Gauthier, F., Alonso, C., Graner, F., Croguennec, T., \& Renault, A. (2000). The protein net electric charge determines the surface rheological properties of ovalbumin adsorbed at the air-water interface. Food Hydrocolloids, 14(5), 463-472.

Ruegg, M., Moor, U., \& Blanc, B. (1977). A calorimetric study of the thermal denaturation of whey proteins in simulated milk ultrafiltrate. Journal of Dairy Research, 44(3), 509-520.

Singh, H. (1995). Heat-induced changes in casein, including interactions with whey proteins. In International Dairy Federation (Ed.), Heat-induced changes in milk, Vol. 9501 (pp. 86-104). Brussels: International Dairy Federation.

Snoeren, T. H. M., \& Van der Spek, C. A. (1977). The isolation of a heat-induced complex from UHTST milk. Netherlands Milk and Dairy Journal, 31(4), 352-355.

van Hooydonk, A. C. M., Hagedoorn, H. G., \& Boerrigter, I. J. (1986). pH-induced physico-chemical changes of casein micelles in milk and their effect on renneting. 1. Effect of acidification on physico-chemical properties. Netherlands Milk and Dairy Journal, 40(2/3), 281-296.

Verheul, M. (1998). Aggregation and gelation of whey proteins. Ph.D. thesis, University Twente, Enschede. 